\title{
Galcanezumab in the prophylaxis of migraine
}

\author{
Galcanezumab w leczeniu profilaktycznym migreny
}

Marcin Kopka

\begin{abstract}
The aim of preventive treatment of episodic and chronic migraine is to reduce the frequency and severity of seizures and thereby improve the quality of patients' lives. It is estimated that $38 \%$ of patients with migraine would benefit from preventive treatment. However, in clinical practice only approximately $13 \%$ of patients with migraine receive it. Intolerable side effects and lack of efficacy of pharmacological treatment are the main reasons of treatment discontinuation. It is suggested that
\end{abstract}

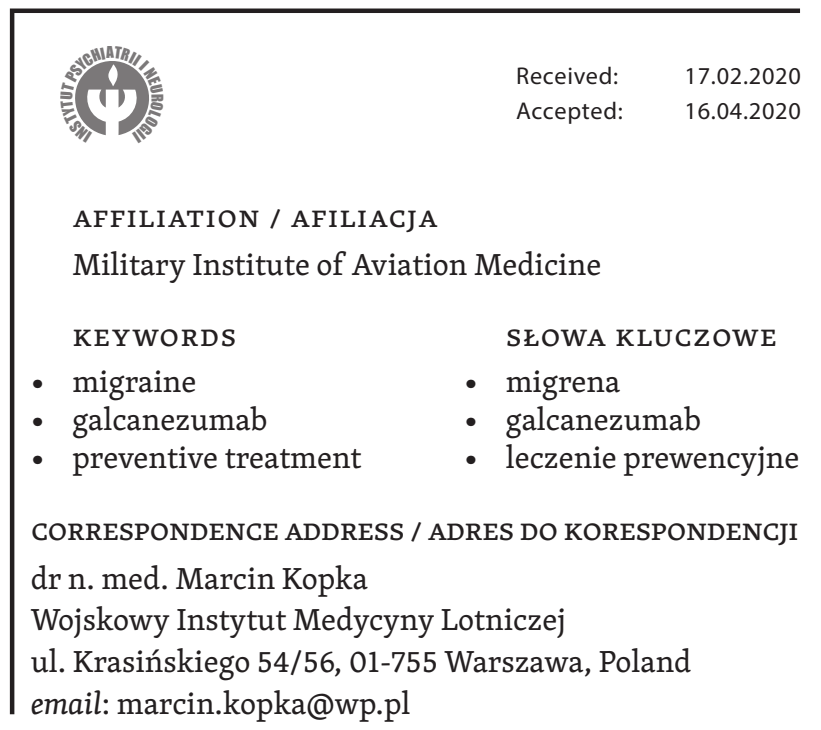

calcitonin-gene-related-peptide (CGRP) plays a critical role in migraine pathophysiology. One of them is galcanezumab - a humanised monoclonal antibody that selectively binds to the CGRP peptide. Galcanezumab has demonstrated efficacy in EVOLVE-1, EVOLVE-2 and REGAIN trials. It significantly reduces migraine days per month versus placebo. Moreover, the quality of patients' lives treated with galcanezumab also improved. It has a favourable safety profile, similar to placebo groups. The most frequent adverse event in patients treated with galcanezumab was injection site pain. No toxic effects on the liver or negative influences on hemodynamic or laboratory parameters were reported. The discontinuation rates due to adverse events in patients treated with galcanezumab were low. In October 2019, lasmiditan was approved by FDA and EMA in prophylaxis treatment of migraine in adult patients. Currently, this medicine is not accessible in Poland.

\section{STRESZCZENIE}

Celem leczenia prewencyjnego epizodycznej oraz przewlekłej migreny jest zmniejszenie częstości oraz ciężkości napadów migreny, a dzięki temu poprawa jakości życia chorych. Szacuje się, że około $38 \%$ chorych na migrenę może odnieść korzyści z leczenia profilaktycznego. Jednakże praktyka kliniczna pokazuje, że otrzymuje je tylko około $13 \%$ chorych. Głównymi powodami przerywania leczenia jest występowanie nietolerowanych objawów ubocznych oraz brak skuteczności leczenia 
farmakologicznego. Sugeruje się, że białko związane $\mathrm{z}$ genem kalcytoniny (ang. calcitonin-gene-related-peptide, CGRP) odgrywa istotną rolę w patofizjologii migreny. Jednym $\mathrm{z}$ nich jest galcanezumab - humanizowane przeciwciało monoklonalne, wybiórczo łączące się z białkiem CGRP. Skuteczność galcanezumabu potwierdzono w badaniach EVOLVE-1, EVOLVE-2 i REGAIN. Jak wykazały wymienione badania, lek ten istotnie zmniejszał ilość dni z migreną w porównaniu z placebo. Ponadto poprawiła się jakość życia pacjentów leczonych galcanezumabem. Lek ten ma korzystny profil działań

\section{Introduction}

Migraine is defined as a recurrent headache characterised by throbbing pain, lasting from 4 to 72 hours, accompanied by nausea and/or hypersensitivity to noise and/or light, intensified during normal physical activity (The International Classification of Headache Disorders, 3rd Edition, 2018). The incidence of migraine in Poland is estimated at approximately $10 \%$ of the total population (Stępień et al. 2013). Preventive treatment is recommended in patients with frequent attacks ( 4 or more migraine headache days per month), especially if they significantly impair the patient's daily functioning (The American Headache Society 2018). Although the results of epidemiological research suggest that it should be used in about $38 \%$ of patients, clinical practice shows that only about $13 \%$ of patients are treated (Lipton et al. 2007). One of the most common reasons for discontinuing preventive treatment is the occurrence of side effects (Hepp et al. 2014). In the last few years, a new group of CGRP antagonists were developed - monoclonal antibodies (calcitonin gene-related peptide antibodies, CGRP Abs).

The purpose of this article is to summarise the available data on the efficacy and safety of one of them, galcanezumab, in the preventive treatment of migraine.

\section{Galcanezumab}

Galcanezumab is a humanised, subcutaneously administered, monoclonal antibody. By binding to the CGRP protein, it prevents its biological activity without inhibiting its receptor (Benschop et al. 2014). On average, galcanezumab reaches its maximum concentration in plasma 5 days after administration. The site of injection does not significantly affect absorption. Galcanezumab is broken down into small peptides and amino acids. Its half-life is about 28 days and can, therefore, be used once a month (Eli Lilly 2018b). Interactions of galcanezumab niepożądanych, podobny jak w grupach placebo. Najczęściej obserwowanym objawem ubocznym u chorych leczonych galcanezumabem był ból w miejscu wkłucia. Nie obserwowano toksycznego wpływu na wątrobę oraz negatywnego wpływu na parametry hemodynamiczne oraz wyniki badań laboratoryjnych. Odsetek chorych leczonych galcanezumabem, którzy przerywali leczenie z powodu objawów ubocznych, był niski. W październiku 2019 roku galcanezumab został zaaprobowany przez FDA oraz EMA w leczeniu profilaktycznym migreny u dorosłych. Aktualnie nie jest dostępny w Polsce.

with other drugs are unlikely because it is not metabolised by cytochrome CYP450 enzymes (Eli Lilly 2018b).

\section{Efficacy}

\section{Episodic migraine}

The efficacy of galcanezumab in the prevention of attacks in patients with episodic migraine and frequent attacks was evaluated in randomised phase 3 clinical trials: EVOLVE-1 and EVOLVE-2 (Stauffer et al. 2018; Skljarevski et al. 2018). The study included patients aged 18 to 65 years with a confirmed diagnosis of migraine according to the ICHD 3 beta classification (The International Classification of Headache Disorders, 3rd edition, 2018), who were diagnosed before the age of 50 , had between 4 and 14 migraine headache days (MHD) per month and at least two attacks during the month preceding the time of taking part in the study (Stauffer et al. 2018; Skljarevski et al. 2018). The study excluded patients with a history of failure to respond to 3 or more preventive treatments (with efficacy levels A and B, as recommended by AAN [Silberstein et al. 2012]), who were treated with anti-CGRP antibodies, as well as patients with other diseases preventing their participation in the trial (pregnancy, suicidal ideation, substance dependence and acute cardiovascular events) (Stauffer et al. 2018; Skljarevski et al. 2018). Ultimately, 858 patients (mostly white women, on average 40.7 years old) were enrolled into the EVOLVE-1 study and randomly assigned to groups treated with $120 \mathrm{mg}(n=213), 240 \mathrm{mg}$ $(n=212)$ dose or placebo $(n=433)$ (Stauffer et al. 2018). In contrast, EVOLVE-2 included 915 patients (mostly white women, on average 41.9 years old) who were randomly assigned to groups treated with $120 \mathrm{mg}(n=231)$, $240 \mathrm{mg}(n=223)$ or placebo $(n=461)$ (Skljarevski et al. 2018). The main endpoint in both studies (EVOLVE-1 and EVOLVE-2) was the average reduction of migraine headache days (MHD) per month. Galcanezumab proved to 
be significantly more effective than placebo, as shown in Table 1.

Table 1. Average reduction of migraine headache days per month

\begin{tabular}{|llll}
\hline & $\begin{array}{l}\text { GALCANEZUMAB } \\
(\mathbf{1 2 0} \mathbf{~ m g )}\end{array}$ & $\begin{array}{l}\text { GALCANEZUMAB } \\
\mathbf{( 2 4 0} \mathbf{~} \mathbf{g})\end{array}$ & PLACEBO \\
EVOLVE-1 & 4.7 days & 4.6 days & 2.8 days \\
EVOLVE-2 & 4.3 days & 4.2 days & 2.3 days \\
REGAIN & 4.8 days & 4.6 days & 2.7 days \\
\hline
\end{tabular}

An additional endpoint (in EVOLVE-1 and EVOLVE-2 studies) was the percentage of patients in whom the number of MHD decreased by at least $50 \%$. It was significantly higher in both studies in patients treated with galcanezumab (both doses), as compared to placebo, which is shown in Table 2.

Table 2. Percentage of patients in whom the average migraine headache days decreased by at least $50 \%$

\begin{tabular}{|llll}
\hline & $\begin{array}{l}\text { GALCANEZUMAB } \\
(\mathbf{1 2 0} \mathbf{~ m g )}\end{array}$ & $\begin{array}{l}\text { GALCANEZUMAB } \\
(\mathbf{2 4 0} \mathbf{~ m g )}\end{array}$ & PLACEBO \\
EVOLVE-1 & $62.3 \%$ & $60.9 \%$ & $38.6 \%$ \\
EVOLVE-2 & $59.3 \%$ & $56.5 \%$ & $36 \%$ \\
REGAIN & $27.6 \%$ & $27.5 \%$ & $15.4 \%$ \\
\hline
\end{tabular}

The results of EVOLVE-1 and EVOLVE-2 studies were confirmed by data from the phase 2 tests. However, the duration of therapy in the second phase was longer ( 6 instead of 3 months).

From a clinical point of view, what is worth emphasising is the rapid effect of galcanezumab. Similarly to other monoclonal antibodies, a statistically significant difference was noted already after the first month of treatment. Moreover, in $20 \%$ of patients treated with galcanezumab (in the EVOLVE-1 and EVOLVE-2 studies), a $50 \%$ reduction in the number of migraine headache days per month was sustained for the entire six months of the study and in $41 \%$ for at least three months (Förderreuther et al. 2018). Following the results of the open phase of the study, the beneficial effect of galcanezumab in reducing MHD was maintained throughout the year of observation (with $120 \mathrm{mg}$ dose the average reduction was 5.6 days and with $240 \mathrm{mg}$ dose the average reduction was 6.5 days) (Camporeale et al. 2018). It is worth emphasising that the benefits of the applied therapy have been achieved both by patients who received preventive treatment in the last five years and those who were untreated (Stauffer et al. 2018). Moreover, in patients treated with galcanezumab, a significant decrease in the number of drugs taken by patients for emergency ad hoc treatment of attacks was observed during the year (Ford et al. 2018).
The lack of a significant response in patients (reduction of MHD by at least 50\%) after the first two months of treatment did not exclude it occurrence later (Nichols et al. 2019). The reduction of MHD by at least $30 \%$ at the beginning of therapy indicates a high probability of obtaining a significant response in the following months of treatment.

\section{Chronic migraine}

The efficacy of galcanezumab in the prevention of attacks in patients with chronic migraine was evaluated in a randomised phase 3 study - REGAIN (Detke et al. 2017). The study included patients aged 18 to 65 years with a confirmed diagnosis of chronic migraine according to the ICHD 3 beta classification, who fell ill before the age of 50 years, and who had (for the last three months before taking part in the study) at least 15 headache days per month, of which at least 8 days met the criteria for migraine. The exclusion criteria for this study were similar to those in the EVOLVE-1 and EVOLVE-2 studies described earlier (Stauffer et al. 2018; Skljarevski et al. 2018). Ultimately, 1113 patients were included in the REGAIN study who were randomly assigned to groups treated with galcanezumab in $120 \mathrm{mg}$ $(n=278), 240 \mathrm{mg}(n=277)$ dose or placebo $(n=558)$. Galcanezumab proved to be significantly more effective in reducing MHD (by 2.1 days with $120 \mathrm{mg}$ dose and by 1.9 days with $240 \mathrm{mg}$ dose) compared to placebo, which is the main endpoint in the study. The results are presented in Table 1. Additional endpoints were the percentage of patients in whom the number of MHD decreased by at least $50 \%$ or $75 \%$. Similarly, the average percentage of patients in whom the number of MHD decreased by at least $50 \%$ (at the dose of $120 \mathrm{mg}$ it was $27.6 \%$ and $240 \mathrm{mg}-27.5 \%$ ) or $75 \%$ (at the dose of $120 \mathrm{mg}$ it was $7 \%$ and $240 \mathrm{mg}-8.8 \%$ ) was significantly higher than in the placebo group ( $15.4 \%$ and $4.5 \%$ respectively). In patients with chronic migraine, a reduction of MHD above $50 \%$ is unlikely if it was not achieved during the first two months of the treatment (Nichols et al. 2019).

\section{Safety}

In addition to its efficacy, the overall assessment of the therapy used should also take into account its safety profile (Dodick et al. 2015). Galcanezumab was well tolerated, and more than $80 \%$ of patients have completed the EVOLVE-1 and EVOLVE-2 studies (Stauffer et al. 2018; Skljarevski et al. 2018). The most commonly observed side effect in patients treated with galcanezumab was pain at the injection site (Detke et al. 2017; Stauffer et al. 2018; Skljarevski et al. 2018). Also, the treated group more frequently than the control group reported itching and swelling at the injection 
site. It should be stressed that these differences were not statistically significant. The side effects were mild to moderate. The percentage of patients interrupting the study due to their occurrence was low and was below 5\% (Stauffer et al. 2018; Skljarevski et al. 2018). It was significantly smaller than in migraine patients treated with topiramate (Brandes et al. 2004; Silberstein et al. 2007).

The favourable safety profile of galcanezumab has been confirmed in an open study lasting one year. No side effects other than those described above were observed (Camporeale et al. 2018). No deaths were reported and serious side effects were rare and, in the opinion of the researchers, they were not related to the treatment used (Detke et al. 2017; Stauffer et al. 2018; Skljarevski et al. 2018). No significant differences in laboratory test reports, ECG or vital signs were noted (Detke et al. 2017; Stauffer et al. 2018; Skljarevski et al. 2018).

In the EVOLVE-1, EVOLVE-2 and REGAIN studies, $17.5 \%$ of patients treated with $120 \mathrm{mg}$ of galcanezumab and $17 \%$ of those treated with $240 \mathrm{mg}$ of galcanezumab had at least one vascular risk factor (defined as the history of ischemic heart disease, hypertension, circulatory failure, cardiomyopathy, dyslipidemia or diabetes) (Oakes et al. 2020). This percentage was similar to that of patients taking placebo (18.5\%). There were no differences in haemodynamic parameters between these groups. Although this may indicate that treatment with galcanezumab does not increase the risk of vascular events, as the authors themselves point out, it requires further studies with longer observation time (Oakes et al. 2020). The most frequently observed side effects after the completion of treatment with galcanezumab were upper respiratory infections. Their incidence was similar to that of placebo groups (Stauffer et al. 2019).

\section{Impact on the quality of life}

Migraine has an adverse effect on the health of people suffering from it both during and between attacks (Dahlof and Dimenas 1995; Freitag et al. 2007). The treatment of migraine should - among other things, by reducing the related impairment - improve the quality of life of patients. Following this assumption, tools to assess the impact of migraine on the daily life of patients were developed and approved (Stewart et al. 1999; Stewart et al. 2001; Cole et al. 2007; Rendas-Baum et al. 2013). The beneficial effect of botulinum toxin treatment on the quality of life of migraine patients has been demonstrated (Lipton et al. 2011), among other things. Topiramate has proven to be as effective as amitriptyline in the prevention of attacks in patients with chronic migraine, but its impact on the quality of life has been more beneficial (Dodick et al. 2009).

In the EVOLVE-1 and EVOLVE-2 studies, galcanezumab was shown to significantly reduce the impairment caused by migraine in groups treated with galcanezumab compared to placebo groups (and this was assessed using a tool called Migraine-Specific Quality of Life Questionnaire, MSQ) (Stauffer et al. 2018; Skljarevski et al. 2018). There was also an improvement in the sense of "severity" of the disease (assessed using the Patient Global Impression of Severity PGI-S questionnaire) (Stauffer et al. 2018; Skljarevski et al. 2018). The patients with chronic migraine treated with galcanezumab, as patients with episodic migraine, showed a beneficial effect on quality of life.

The REGAIN study showed an improvement in the sense of "severity" of the disease in the treated groups compared to the placebo group (assessed using the PGI-S questionnaire) (Detke et al. 2017). Due to methodological differences, the possibilities of comparing the results of these treatments are limited. For example, in the EVOLVE-1 and EVOLVE-2 studies, significant improvement was demonstrated after just one month of treatment (using MSQ for the assessment), while in topiramate studies, the first assessments were made not until after two months of treatment (Ford et al. 2019).

\section{Conclusions}

In randomised phase 3 clinical trials, the efficacy of galcanezumab in the prevention of migraine attacks was confirmed in both episodic (EVOLVE-1 and EVOLVE-2) and chronic (REGAIN) migraine patients (Detke et al. 2017; Stauffer et al. 2018; Skljarevski et al. 2018). The treatment has proven to be effective both in reducing the number of migraine headache days per month and in the percentage of patients responding to treatment. The effects of galcanezumab treatment lasted for several months after the end of the therapy (Stauffer et al. 2019). In general, the therapy was well tolerated and the percentage of patients resigning from the study was low.

In September 2018 galcanezumab was approved by the FDA and EMA for the prophylactic treatment of migraine in adults (Eli Lilly 2018a). The drug is not currently available in Poland.

A REBUILD study (NCT03559257) is currently underway to assess the efficacy and safety of galcanezumab in the treatment of episodic migraine in the paediatric population. On the other hand, the CONQUER study (NCT03559257) was completed to assess the efficacy and safety of galcanezumab in patients with refractory episodic and chronic migraine. Its results have not been published yet. 


\section{Wprowadzenie}

Migrena (ang. migraine) definiowana jest jako nawracający ból głowy charakteryzujący się napadami bólu o pulsującym charakterze, trwającymi od 4 do 72 godzin, z towarzyszącymi nudnościami i/lub nadwrażliwością na hałas i/lub światło, nasilający się podczas zwykłej aktywności fizycznej (The International Classification of Headache Disorders, 3rd edition, 2018). Częstość występowania migreny w Polsce szacowana jest na około 10\% ogólnej populacji (Stępień et al. 2013). U chorych z częstymi napadami (4 lub więcej dni z migreną w miesiącu), a zwłaszcza znacząco upośledzającymi codzienne funkcjonowanie chorego, zalecane jest stosowanie leczenia profilaktycznego (The American Headache Society 2018). Chociaż wyniki badań epidemiologicznych sugerują, że powinno być ono stosowane u około $38 \%$ chorych, to praktyka kliniczna pokazuje, że leczonych jest tylko około 13\% (Lipton et al. 2007). Jednym z najczęstszych powodów przerwania leczenia prewencyjnego jest wystąpienie objawów ubocznych (Hepp et al. 2014). W ciągu ostatnich kilku lat opracowano nową grupę leków blokujących CGRP - przeciwciała monoklonalne (calcitonin gene related peptide antibodies, CGRP Abs).

Celem niniejszego artykułu jest podsumowanie dostępnych danych dotyczących skuteczności oraz bezpieczeństwa stosowania jednego z nich - galcanezumabu - w leczeniu prewencyjnym migreny.

\section{Galcanezumab}

Galcanezumab jest humanizowanym, podawanym podskórnie, przeciwciałem monoklonalnym. Poprzez łączenie się z białkiem CGRP zapobiega jego biologicznej aktywności bez blokowania jego receptora (Benschop et al. 2014). Maksymalne stężenie w osoczu galcanezumab osiąga średnio po 5 dniach od podania. Miejsce iniekcji nie wpływa istotnie na absorpcję. Galcanezumab rozkładany jest na małe peptydy oraz aminokwasy. Czas jego półtrwania wynosi około 28 dni i dzięki temu może być stosowany raz w miesiącu (Eli Lilly 2018b). Interakcje galcanezumabu z innymi lekami są mało prawdopodobne, ponieważ nie jest metabolizowany przez enzymy cytochromu CYP450 (Eli Lilly 2018b).

\section{Skuteczność}

\section{Migrena epizodyczna}

Skuteczność galcanezumabu w profilaktyce napadów u chorych z migreną epizodyczną i częstymi napadami oceniano w randomizowanych badaniach klinicznych trzeciej fazy: EVOLVE-1 oraz EVOLVE-2 (Stauffer et al. 2018; Skljarevski et al. 2018). Do udziału w badaniach włączano chorych w wieku od 18 do 65 lat, z potwierdzonym rozpoznaniem migreny zgodnie z klasyfikacją ICHD 3 beta (The International Classification of Headache Disorders, 3rd edition, 2018), którzy zachorowali przed ukończeniem 50. roku życia, mieli od 4 do 14 dni z migrenowym bólem głowy w miesiącu (migraine headache days, MHD) oraz co najmniej dwa napady w ciągu miesiąca poprzedzającego włączenie (Stauffer et al. 2018; Skljarevski et al. 2018). Z badań wykluczano chorych, u których stosowanie trzech lub więcej terapii profilaktycznych (o poziomie skuteczności A i B, zgodnie z rekomendacjami AAN [Silberstein et al. 2012]) okazało się nieskuteczne, leczonych - zgodnie z danymi z wywiadu - przeciwciałami przeciw CGRP oraz chorych z innymi schorzeniami uniemożliwiającymi udział w badaniu (ciąża, myśli samobójcze, uzależnienie od leków oraz ostre incydenty sercowo-naczyniowe) (Stauffer et al. 2018; Skljarevski et al. 2018). Ostatecznie do badania EVOLVE-1 włączono 858 chorych (w większości kobiety rasy białej, w wieku średnio 40,7 lat), których losowo przydzielono do grup leczonych galcanezumabem w dawce $120 \mathrm{mg}(n=213), 240 \mathrm{mg}(n=212)$ lub placebo $(n=433)$ (Stauffer et al. 2018). Natomiast do badania EVOLVE-2 włączono 915 chorych (w większości kobiety rasy białej, w wieku średnio 41,9 lat), których losowo przydzielono do grup leczonych galcanezumabem $w$ dawce $120 \mathrm{mg}(n=231), 240 \mathrm{mg}(n=223)$ lub placebo $(n=461)$ (Skljarevski et al. 2018). Głównym punktem końcowym w obu badaniach (EVOLVE-1 i EVOLVE-2) była średnia redukcja ilości dni z migreną (MHD) w miesiącu. Galcanezumab okazał się istotnie skuteczniejszy w porównaniu z placebo, co przedstawiono w tabeli 1.

Tabela 1. Średnia redukcja ilości dni z migreną w miesiącu

\begin{tabular}{|llll}
\hline & $\begin{array}{l}\text { GALCANEZUMAB } \\
(\mathbf{1 2 0} \mathbf{~ m g})\end{array}$ & $\begin{array}{l}\text { GALCANEZUMAB } \\
(\mathbf{2 4 0} \mathbf{~ m g})\end{array}$ & PLACEBO \\
EVOLVE-1 & 4,7 dnia & 4,6 dnia & 2,8 dnia \\
EVOLVE-2 & 4,3 dnia & 4,2 dnia & 2,3 dnia \\
REGAIN & 4,8 dnia & 4,6 dnia & 2,7 dnia \\
\hline
\end{tabular}

Dodatkowym punktem końcowym (w badaniach EVOLVE-1 oraz EVOLVE-2) były odsetki chorych, u których ilość MHD zmniejszyła się co najmniej o 50\%. Były one istotnie wyższe w obu badaniach u chorych leczonych galcanezumabem (obiema dawkami), w porównaniu z placebo, co przedstawiono w tabeli 2.

Tabela 2. Odsetek chorych, u których średnia ilość dni z migreną zmniejszyła się o co najmniej o $50 \%$

\begin{tabular}{|llll}
\hline & $\begin{array}{l}\text { GALCANEZUMAB } \\
(\mathbf{1 2 0} \mathbf{~ m g )}\end{array}$ & $\begin{array}{l}\text { GALCANEZUMAB } \\
(\mathbf{2 4 0} \mathbf{~ m g )}\end{array}$ & PLACEBO \\
EVOLVE-1 & $62,3 \%$ & $60,9 \%$ & $38,6 \%$ \\
EVOLVE-2 & $59,3 \%$ & $56,5 \%$ & $36 \%$ \\
REGAIN & $27,6 \%$ & $27,5 \%$ & $15,4 \%$ \\
\hline
\end{tabular}


Wyniki badań EVOLVE-1 oraz EVOLVE-2 zostały potwierdzone danymi z badań drugiej fazy. Czas trwania terapii w drugiej fazie badań był jednak dłuższy (6 miesięcy zamiast 3 miesięcy).

Z klinicznego punktu widzenia warte podkreślenia jest szybkie działanie galcanezumabu. Istotną statystycznie różnicę odnotowywano, podobnie jak w przypadku innych przeciwciał monoklonalnych, już po pierwszym miesiącu leczenia. Ponadto u $20 \%$ chorych leczonych galcanezumabem (w badaniach EVOLVE-1 oraz EVOLVE-2) większa niż o 50\% redukcja w ilości dni z migreną w miesiącu utrzymywała się przez całe sześć miesięcy trwania badania, a u $41 \%$ przez co najmniej trzy miesiące (Förderreuther et al. 2018). Zgodnie z wynikami otwartej fazy badania, korzystne działanie galcanezumabu w redukcji MHD utrzymywało się przez cały rok obserwacji (przy dawce $120 \mathrm{mg}$ średnio o 5,6 dnia, a przy dawce $240 \mathrm{mg}$ średnio o 6,5 dnia) (Camporeale et al. 2018). Warto podkreślić, że korzyści z zastosowanej terapii odnieśli zarówno chorzy, którzy w ciągu ostatnich pięciu lat otrzymywali leczenie prewencyjne, jak i chorzy, którzy nie byli leczeni (Stauffer et al. 2018). Ponadto u chorych leczonych galcanezumabem odnotowano w ciągu roku istotne zmniejszenie ilości leków przyjmowanych przez chorych celem doraźnego leczenia napadów (Ford et al. 2018). Brak u chorych istotnej reakcji (redukcja MHD co najmniej o 50\%) po pierwszych dwóch miesiącach leczenia nie wykluczał jej uzyskania później (Nichols et al. 2019). Redukcja ilości MHD co najmniej o 30\% na początku terapii wskazuje na duże prawdopodobieństwa uzyskania istotnej reakcji w następnych miesiącach leczenia.

\section{Migrena przewlekła}

Skuteczność galcanezumabu w profilaktyce napadów u chorych z migreną przewlekłą oceniano w randomizowanym badaniu trzeciej fazy: REGAIN (Detke et al. 2017). Włączano do niego chorych w wieku od 18 do 65 lat z potwierdzonym rozpoznaniem migreny przewlekłej zgodnie z klasyfikacją ICHD 3 beta, którzy zachorowali przed 50. rokiem życia, mieli (przez ostatnie trzy miesiące przed włączeniem do badania) co najmniej $15 \mathrm{dni}$ z bólem głowy w miesiącu, z czego przez co najmniej 8 dni spełniał on kryteria migreny. Kryteria wykluczenia z udziału w tym badaniu były podobne jak we wspomnianych wcześniej badaniach EVOLVE-1 i EVOLVE-2 (Stauffer et al. 2018; Skljarevski et al. 2018). Ostatecznie do badania REGAIN włączono 1113 chorych, których przydzielono losowo do grup leczonych galcanezumabem w dawce $120 \mathrm{mg}(n=278), 240 \mathrm{mg}(n=277)$ lub placebo $(n=558)$. Galacanezumab okazał się istotnie skuteczniejszy w redukcji MHD (o 2,1 dnia u leczonych dawką $120 \mathrm{mg}$ oraz o 1,9 dnia - u leczonych dawką $240 \mathrm{mg}$ ) w porównaniu z placebo - główny punkt końcowy w badaniu. Wyniki przedstawiono w tabeli 1. Dodatkowymi punktami końcowymi były odsetki chorych, u których ilość MHD zmniejszyła się co najmniej o 50\% lub 75\%. Podobnie średni odsetek chorych, u których ilość MHD zmniejszyła się co najmniej o 50\% (przy dawce $120 \mathrm{mg}$ wynosił $27,6 \%$, a $240 \mathrm{mg}-27,5 \%$ ) lub $75 \%$ (przy dawce $120 \mathrm{mg}$ wynosił $7 \%$, a $240 \mathrm{mg}-8,8 \%$ ), był istotnie wyższy niż w grupie przyjmującej placebo (odpowiednio $15,4 \%$ i 4,5\%). U chorych na migrenę przewlekłą redukcja MHD powyżej 50\% jest mało prawdopodobna, jeśli nie uzyskano jej przez pierwsze dwa miesiące leczenia (Nichols et al. 2019).

\section{Bezpieczeństwo}

W ogólnej ocenie stosowanej terapii, poza jej skutecznością, należy również brać pod uwagę jej profil bezpieczeństwa (Dodick et al. 2015). Galcanezumab był dobrze tolerowany, a ponad $80 \%$ chorych ukończyło badania EVOLVE-1 i EVOLVE-2 (Stauffer et al. 2018; Skljarevski et al. 2018). Najczęściej obserwowanym objawem ubocznym u chorych leczonych galcanezumabem był ból w miejscu wkłucia (Detke et al. 2017; Stauffer et al. 2018; Skljarevski et al. 2018). Ponadto w grupie leczonej, częściej niż w kontrolnej, odnotowywano świąd oraz obrzęk w miejscu wkłucia. Należy podkreślić, że różnice te nie były istotne statystycznie. Objawy uboczne miały nasilenie łagodne lub umiarkowane. Odsetek chorych przerywających udział w badaniu z powodu ich wystąpienia był niski i wynosił poniżej 5\% (Stauffer et al. 2018; Skljarevski et al. 2018). Był on istotnie mniejszy niż u chorych z migreną leczonych topiramatem (Brandes et al. 2004; Silberstein et al. 2007). Korzystny profil bezpieczeństwa galcanezumabu potwierdzono $\mathrm{w}$ trwającym rok otwartym badaniu. Nie zobserwowano w nim innych objawów ubocznych niż opisane wcześniej (Camporeale et al. 2018). Nie odnotowano zgonów, a poważne objawy uboczne występowały rzadko i w opinii badaczy nie miały związku ze stosowanym leczeniem (Detke et al. 2017; Stauffer et al. 2018; Skljarevski et al. 2018). Nie odnotowano istotnych różnic między badanymi grupami w wynikach badań laboratoryjnych, EKG oraz parametrach życiowych (Detke et al. 2017; Stauffer et al. 2018; Skljarevski et al. 2018). W badaniach EVOLVE-1, EVOLVE-2 oraz REGAIN u 17,5\% chorych leczonych galcanezumabem w dawce $120 \mathrm{mg}$ oraz u $17 \%$ leczonych galcanezumabem w dawce $240 \mathrm{mg}$ stwierdzono co najmniej jeden naczyniowy czynnik ryzyka (definiowany jako występowanie w wywiadzie: choroby niedokrwiennej serca, nadciśnienia tętniczego, niewydolności krążenia, kardiomiopatii, dyslipidemii lub cukrzycy) (Oakes et al. 2020). Odsetek ten był podobny jak w wypadku chorych przyjmujących placebo $(18,5 \%)$. Nie odnotowano różnic w parametrach hemodynamicznych między tymi grupami. Chociaż może to wskazywać, że leczenie galcanezumabem nie zwiększa ryzyka wystąpienia incydentów naczyniowych, jak zaznaczają 
sami autorzy, wymaga jednak przeprowadzenia dalszych badań z dłuższym czasem obserwacji (Oakes et al. 2020). Najczęściej obserwowanymi objawami ubocznymi po ukończeniu leczenia galcanezumabem były infekcje górnej części układu oddechowego. Częstość ich występowania była podobna jak w grupach placebo (Stauffer et al. 2019).

\section{Wpływ na jakość życia}

Migrena wpływa niekorzystnie na zdrowie osób na nią cierpiących zarówno w czasie napadów, jak i pomiędzy nimi (Dahlof i Dimenas 1995; Freitag et al. 2007). Leczenie migreny powinno - między innymi poprzez zmniejszenie związanego z nią upośledzenia - przynieść poprawę jakości życia chorych. Zgodnie z tym założeniem opracowano oraz zatwierdzono narzędzia służące ocenie wpływu migreny na codzienne życie chorych (Stewart et al. 1999; Stewart et al. 2001; Cole et al. 2007; Rendas-Baum et al. 2013). Wykazano między innymi korzystny wpływ leczenia za pomocą toksyny botulinowej na jakość życia chorych z migreną (Lipton et al. 2011). Topiramat okazał się równie skuteczny jak amitryptylina w profilaktyce napadów u chorych z migreną przewlekłą, jednak jego wpływ na jakość życia był korzystniejszy (Dodick et al. 2009). W badaniach EVOLVE-1 oraz EVOLVE-2 w grupach leczonych galcanezumabem w porównaniu z grupami placebo wykazano istotne zmniejszenie upośledzenia spowodowanego migreną (a oceniano to za pomocą narzędzia o nazwie Migraine-Specific Quality of Life Questionnaire, MSQ) (Stauffer et al. 2018; Skljarevski et al. 2018). Odnotowano również poprawę w zakresie poczucia „ciężkości" schorzenia (oceniano je za pomocą kwestionariusza Patient Global Impression of Severity PGI-S) (Stauffer et al. 2018; Skljarevski et al. 2018). Podobnie jak u chorych z migreną epizodyczną, również w migrenie przewlekłej u chorych leczonych galcanezumabem wykazano korzystny wpływ na jakość życia. W badaniu
REGAIN w grupach leczonych w porównaniu z grupą placebo wykazano poprawę w zakresie poczucia „ciężkości” schorzenia (oceniano za pomocą kwestionariusza PGI-S) (Detke et al. 2017). Z uwagi na różnice metodologiczne, możliwości porównania wyników wspomnianych terapii są ograniczone. Na przykład w badaniach EVOLVE-1 oraz EVOLVE-2 istotną poprawę wykazywano już po miesiącu terapii (wykorzystując do oceny MSQ), natomiast w badaniach z zastosowaniem topiramatu pierwszych ocen dokonywano dopiero po dwóch miesiącach leczenia (Ford et al. 2019).

\section{Wnioski}

W randomizowanych badaniach klinicznych trzeciej fazy potwierdzono skuteczność galcanezumabu w profilaktyce napadów migreny zarówno u chorych z migreną epizodyczną (EVOLVE-1 I EVOLVE-2), jak i przewlekłą (REGAIN) (Detke et al. 2017; Stauffer et al. 2018; Skljarevski et al. 2018). Leczenie okazało się skuteczne zarówno w zakresie redukcji liczby dni z migreną w miesiącu, jak i odsetka chorych reagujących na leczenie. Efekty leczenia galcanezumabem utrzymywały się do kilku miesięcy od zakończenia terapii (Stauffer et al. 2019). Ogólnie rzecz ujmując, terapia była dobrze tolerowana, a odsetek chorych rezygnujących z udziału w badaniu niski. We wrześniu 2018 roku galcanezumab został zaaprobowany przez FDA oraz EMA w leczeniu profilaktycznym migreny u dorosłych (Eli Lilly 2018a). Lek nie jest aktualnie dostępny w Polsce. Obecnie trwa badanie REBUILD (NCT03559257), którego celem jest ocena skuteczności oraz bezpieczeństwa stosowania galcanezumabu w leczeniu migreny epizodycznej w populacji pediatrycznej. Zakończyło się natomiast badanie CONQUER (NCT03559257), którego celem była ocena skuteczności oraz bezpieczeństwa stosowania galcanezumabu u chorych z oporną na leczenie migreną epizodyczną oraz przewlekłą. Jego wyników jeszcze nie opublikowano.
Conflict of interest and financial support non declared. / Nie zgłoszono konfliktu interesów oraz dofinansowania.

The work described in this article has been carried out in accordance with The Code of Ethics of the World Medical Association (Declaration of Helsinki) for experiments involving humans, EU Directive 2010/63/EU for animal experiments, and Uniform Requirements for manuscripts submitted to biomedical journals. / Treści przedstawione w artykule są zgodne z zasadami Deklaracji Helsińskiej, dyrektywami EU oraz ujednoliconymi wymaganiami dla czasopism biomedycznych.

Wkład autorów / Authors' contributions: Marcin Kopka 100\%.

\section{References / Piśmiennictwo}

1. Brandes JL, Saper JR, Diamond M et al. Topiramate for migraine prevention: A randomized controlled trial. JAMA 2004; 291: 965-973.

2. Benschop RJ, Collins EC, Darling RJ, Allan BW, Leung D, Conner EM et al. Development of a novel antibody to calcitonin gene-related peptide for the treatment of osteoarthritis-related pain. Osteoarthr Cartil 2014; 22: 578-585.

3. Camporeale A, Kudrow D, Sides R, Wang S, Van Dycke A, Selzler KJ et al. A phase 3, long-term, open-label safety study of Galcanezumab in patients with migraine. BMC Neurol. 2018; 18(1): 188. 
4. Cole JC, Lin P, Rupnow MF. Validation of the Migraine-Specific Quality of Life Questionnaire version 2.1 (MSQ v. 2.1) for patients undergoing prophylactic migraine treatment. Qual Life Res 2007; 16: 1231-1237.

5. Dahlof C, Dimenas E. Migraine patients experience poorer subjective well-being/quality of life even between attacks. Cephalalgia 1995; 15(1): 31-36.

6. Detke HC, Wang S, Skljarevski V, Ahl J, Millen B, Aurora S et al. A Phase 3 Placebo-Controlled Study of Galcanezumab in Patients with Chronic Migraine: Results from the 3-month Double-Blind Treatment Phase of the REGAIN Study 59th Annual Scientific Meeting American Headache Society June 8-11, 2017.

7. Dodick DW, Freitag F, Banks J, Saper J, Xiang J, Rupnow M et al. Topiramate versus amitriptyline in migraine prevention: a 26-week, multicenter, randomized, double-blind, double-dummy, parallel-group noninferiority trial in adult migraineurs. Clin Ther 2009; 31: 542-559.

8. Dodick DW, Turkel CC, DeGryse RE, Diener HC, Lipton RB, Aurora SK et al. Assessing clinically meaningful treatment effects in controlled trials: chronic migraine as an example. J Pain 2015; 16: 164-175.

9. Eli Lilly and Company. Lilly's Emgality ${ }^{\mathrm{TM}}$ (galcanezumabgnlm) receives U.S. FDA approval for the preventive treatment of migraine in adults [media release]. 5 Oct $2018 \mathrm{a}$. https://investor.lilly.com/

10. Eli Lilly and Company. EMGALITY (galcanezumab-gnlm) injection, for subcutaneous use: US prescribing information. 2018. http://pi.lilly.com/. Accessed 11 Oct 2018b.

11. Ford JH, Ayer DW, Zhang Q, Carter JN, Leroux E, Skljarevski V et al. Two randomized migraine studies of galcanezumab: Effects on patient functioning and disability. Neurology 2019; 93(5): e508-e517.

12. Ford JH, Foster SA, Stauffer VL, Aurora SK, Versijpt J, Satisfaction P. Patient satisfaction, health care resource utilization, and acute headache medication use with galcanezumab: results from a 12-month open-label study in patients with migraine. Patient Prefer Adherence. 2018; 12: 2413-2424.

13. Förderreuther S, Zhang Q, Stauffer VL, Aurora SK, Láinez MJA. Preventive effects of galcanezumab in adult patients with episodic or chronic migraine are persistent: data from the phase 3 , randomized, double-blind, placebo-controlled EVOLVE-1, EVOLVE-2, and REGAIN studies. J Headache Pain. 2018; 19(1): 121.

14. Freitag F. The cycle of migraine: Patients' quality of life during and between migraine attacks. Clinical Therapy 2007; 29(5): 939-949.

15. Hepp Z, Bloudek LM, Varon SF. Systematic review of migraine prophylaxis adherence and persistence. J Manag Care Pharm. 2014; 20: 22-33.

16. Lipton RB, Bigal ME, Diamond M, Freitag F, Reed ML, Stewart WF et al. The American Migraine Prevalence and Prevention Advisory Group. Migraine prevalence, disease burden, and the need for preventive therapy. Neurology 2007; 68: 343-349.

17. Lipton RB, Varon SF, Grosberg B, McAllister PJ, Freitag F, Aurora SK et al. OnabotulinumtoxinA improves quality of life and reduces impact of chronic migraine. Neurology 2011; 77: 1465-1472.
18. Nichols R, Doty E, Sacco S, Ruff D, Pearlman E, Aurora SK. Analysis of Initial Nonresponders to Galcanezumab in Patients With Episodic or Chronic Migraine: Results From the EVOLVE-1, EVOLVE-2, and REGAIN Randomized, Double-Blind, Placebo-Controlled Studies. Headache 2019; 59(2): 192-204.

19. Oakes TM, Kovacs R, Rosen N, Doty E, Kemmer P, Aurora SK et al. Evaluation of Cardiovascular Outcomes in Adult Patients With Episodic or Chronic Migraine Treated With Galcanezumab: Data From Three Phase 3, Randomized, Double-Blind, Placebo-Controlled EVOLVE-1, EVOLVE-2, and REGAIN Studies. Headache 2020; 60(1): 110-123.

20. Rendas-Baum R, Bloudek LM, Maglinte GA, Varon SF. The psychometric properties of the Migraine-Specific Quality of Life Questionnaire version 2.1 (MSQ) in chronic migraine patients. Qual Life Res 2013; 22: 1123-1133.

21. Silberstein SD, Holland S, Freitag F, Dodick DW, Argoff C, Ashman E. Quality Standards Subcommittee of the American Academy of Neurology and the American Headache Society. Evidence-based guideline update: pharmacologic treatment for episodic migraine prevention in adults: report of the Quality Standards Subcommittee of the American Academy of Neurology and the American Headache Society. Neurology 2012; 78(17): 1337-1345.

22. Silberstein SD, Lipton RB, Dodick DW, Freitag FG, Ramadan $\mathrm{N}$, Mathew $\mathrm{N}$ et al. Efficacy and safety of topiramate for the treatment of chronic migraine: A randomized, double-blind, placebo-controlled trial. Headache 2007; 47: 170-180.

23. Skljarevski V, Matharu M, Millen BA, Ossipov MH, Kim BK, Yang JY. Efficacy and safety of galcanezumab for the prevention of episodic migraine: Results of the EVOLVE-2 Phase 3 randomized controlled clinical trial. Cephalalgia 2018; 38(8): 1442-1454.

24. Stauffer VL, Dodick DW, Zhang Q, Carter JN, Ailani J, Conley RR. Evaluation of Galcanezumab for the Prevention of Episodic Migraine: The EVOLVE-1 Randomized Clinical Trial. JAMA Neurol 2018; 75(9): 1080-1088.

25. Stauffer VL, Wang S, Voulgaropoulos M, Skljarevski V, Kovacik A, Aurora SK. Effect of Galcanezumab Following Treatment Cessation in Patients With Migraine: Results From 2 Randomized Phase 3 Trials. Headache 2019; 59(6): 834-847.

26. Stewart WF, Lipton RB, Kolodner K, Liberman J, Sawyer J. Reliability of the Migraine Disability Assessment Score in a population-based sample of headache sufferers. Cephalalgia 1999; 19: 107-114.

27. Stewart WF, Lipton RB, Dowson AJ, Sawyer J. Development and testing of the Migraine Disability Assessment (MIDAS) questionnaire to assess headache-related disability. Neurology 2001; 56: S20-S28.

28. Stępień A, Prusiński A, Suwała A. Wybrane dane epidemiologiczne występowania migreny w Polsce. Ból 2013; 4(3): 9-12.

29. The American Headache Society Position Statement On Integrating New Migraine Treatments Into Clinical Practice. Headache. 2018 Dec 10. doi:10.1111/head.13456

30. The International Classification of Headache Disorders, 3rd edition. Cephalalgia 2018; 38(1): 1-211. 